\title{
THE BARORESPONSES OF PRETERM INFANTS DURING HALOTHANE ANAESTHESIA
}

\author{
George A. Gregory
}

\begin{abstract}
Anaesthetics depress the baroresponse of adults. If the same is true of infants, they will have difficulty maintaining their cardiac output if they become hypotensive because they are primarily rate dependent for cardiac output. The opportunity to test whether anaesthetics depress the baro-response of neonates arose while anaesthetizing preterm infants for ligation of patent ductus arteriosus.

The relationship between heart rate and the systolic blood pressure (baroresponse) was examined in 53 preterm infants $(1,065 \pm 205 \mathrm{~g})$ receiving $0.5-1.0$ per cent inspired halothane for ligation of patent ductus arteriosus. The arterial pressure was measured by indwelling catheters and strain gauges ( 43 patients) or a doppler device ( 10 patients). Heart rate was measured with skin electrodes. The relationship between heart rate and systolic pressure was examined before and after the induction of anaesthesia and before and after ligation of the ductus.

Just before ligation of the ductus arteriosus the systolic blood pressure had decreased 33 per cent from awake control values without a change in heart rate. Five minutes after the ductus was ligated the arterial pressure had increased 38 per cent, again without a change in heart rate. The differences between systolic pressures was highly statistically significant in both instances $(P<0.001)$. The differences between heart rate were not.

These data indicate a lack of baroresponse in these preterm infants during light halothane anaesthesia which may alter their ability to maintain cardiac output when hypotensive.
\end{abstract}

KEY WoRDS: ANAESTHESIA, paediatric, preterm infants, baroreceptor response; ANAESTHETICS, VOLATILE, halothane.

BETWEEN five and ten per cent of preterm infants weighing $<1500 \mathrm{~g}$ at birth develop a patent ductus arteriosus with congestive heart failure and require anaesthesia and operation for its ligation ${ }^{1}$ More than fifty per cent of these infants become hypotensive during anaesthesia (a decrease in systolic pressure of more than thirty per cent). ${ }^{*}$ Hypotension is also more frequent when older infants and children are anaesthetized than in anaesthetized adults. ${ }^{2}$ Normally the awake adult compensates for hypotension by increasing heart rate, myocardial contractility and peripheral vascular resistance. Anaesthesia attenuates this ability to compensate by blocking the reflex increase in heart rate. ${ }^{3,4}$ Since the infant is normally rate dependent for cardiac output, failure to increase heart rate during bouts of hypotension (lack of baroresponse) would reduce his ability to effectively compensate for hypotension. Since preterm infants are com-

George A. Gregory, M.D. Departments of Anesthesia and Pediatrics and the Cardiovascular Research Institute, University of California, San Francisco, California 94143, U.S.A.

Can. Anaesth. Soc. J., vol. 29, no. 2, March 1982 monly hypotensive during anaesthesia, we determined whether their baroresponse was present or absent during anaesthesia and operation for ligation of patent ductus arteriosus.

\section{METHODS}

Since for ethical reasons we were unable to test for the presence or absence of baroresponses in these infants by infusing vasoactive drugs, ${ }^{3,4}$ we sought another means of doing so. We had previously noted a consistent rise in the arterial pressure when the ductus arteriosus was ligated. This gave us the opportunity to examine the relationship between arterial pressures and heart rate and thus to determine whether the baroresponse was present or absent. We reviewed the anesthetic records of 53 consecutive infants who weighed less than 1500 grams at birth and who required ligation of a patent ductus arteriosus.* None of the patients received atropine before or during anaesthesia as was our custom before

*Permission was obtained from the Committee on Human Research to review the records. 
TABLE I

The Relationship Between Heart Rate and Systolic Blood Pressure in Preterm Infants Anesthetized with Halothane

\begin{tabular}{lcc}
\hline \multicolumn{1}{c}{ Condition } & $\begin{array}{c}\text { Heart Rate } \\
\text { Beats/Min }\end{array}$ & $\begin{array}{c}\text { Systolic Pressure } \\
\mathrm{kPa}(\text { (tor) }\end{array}$ \\
\hline Pre-induction & $146 \pm 20$ & $8.24 \pm 2.13(62 \pm 16)$ \\
Pre-ductal ligation & $143 \pm 17$ & $6.38 \pm 2.13(48 \pm 16)$ \\
Post-ductal ligation & $145 \pm 16$ & $8.78 \pm 1.99(66 \pm 15) \dagger$ \\
\hline
\end{tabular}

*Significantly different from awake.

tSignificantly different from that present prior to ligation of the ductus arteriosus.

Barach, et al. demonstrated that atropine may improve cardiac output during anaesthesia. ${ }^{5}$ All infants were anaesthetized with halothane $(0.5$ to 1.0 per cent inspired) in air and enough oxygen to maintain $\mathrm{Pa}_{0}$, between 6.65 and $9.31 \mathrm{kPa}$ (50-70 torr). Five infants were paralyzed with d-tubocurarine $0.05 \mathrm{mg} \cdot \mathrm{kg}^{-1}$. On the average, they received $5-10 \mathrm{ml} \cdot \mathrm{kg}^{-1} / \mathrm{hr}$ of D5-Ringer's lactate during operation. All required mechanical ventilation before, during, and after operation. The arterial pressure was measured continuously from an indwelling arterial catheter (umbilical or radial) in 43 patients and every five minutes with a Doppler device in ten. The heart rate and electrocardiogram were recorded continuously with skin electrodes. Both were recorded on the anesthetic record every five minutes by one of the two physicians present. I compared the heart rate and arterial pressure before induction of anaesthesia and before and five minutes after ligation of the ductus arteriosus. Data were compared by paired t-test and one way analysis of variance.

\section{RESULTS}

The infants weighed $1108 \pm 182$ grams (range 580 to $1450 \mathrm{~g}$ ) at birth. At operation they weighed $1065 \pm 205$ grams (range 680 to $1500 \mathrm{~g}$ ). Eighty per cent underwent surgery because of intractable congestive heart failure. The other 20 per cent. were operated upon because of early necrotizing enterocolitis plus congestive heart failure. We defined hypotension as a systolic arterial pressure below $6 \mathrm{kPa}$ (45 torr). Ten infants were hypotensive when they arrived in the operating room and had their arterial blood pressure returned to nomal with $5-10 \mathrm{ml} \cdot \mathrm{kg}^{-1}$ of normal saline (Table I). Just before ligation of the ductus the mean systolic blood pressure had decreased to $5.32 \pm 2.13 \mathrm{kPa}$ ( $40 \pm 16$ torr), a 33 per cent change from control $(P<0.001)$, without a change in heart rate. Five minutes after ligating the ductus arteriosus the systolic blood pressure was $8.6 \pm 2 \mathrm{kPa}(65 \pm$ 15 torr), an increase of 38 per cent. The heart rate did not change. In other words, despite the 38 per cent increase in systolic blood pressure, the heart rate remained constant. The difference between the systolic pressures was significant at the 0.001 level by the paired t-test, while the differences between the heart rates were not $(\mathrm{P}>0.3)$.

\section{Discussion}

Retrospective studies such as this may be difficult to interpret because the data were not initially collected with a specific question in mind. Therefore there may be a question about their validity. The author recognizes this fact. However, I was present for 60 per cent of the cases and consulted preoperatively with the attending anaesthetist on the others. One of the two physicians present recorded the vital signs while the other administered the anaesthetic. All data pertinent to this study were available in each case. In addition, the data were consistent. The arterial pressure rose in every case following ligation of the ductus arteriosus while the heart rate remained constant. Therefore, I believe the data are valid.

The baroreceptors of term infants are present and active. ${ }^{6}$ To our knowledge they have not been previously studied in preterm infants for ethical and technical reasons. The changes in arterial pressure seen during anaesthesia and operation gave me the opportunity to examine whether the preterm infant's baroresponses were active. They were not, as indicated by a constant heart rate despite a 33 per cent decrease in the systolic arterial pressure following the induction of anaesthesia and a 38 per cent increase following ligation of the ductus arteriosus. Thus neither a decrease nor an increase in arterial pressure resulted in a change in heart rate, indicating an absence of the baroresponse.

Halothane is known to depress the barore- 
sponse of healthy adults. ${ }^{4}$ These data indicate that this is also true in our preterm infants even at halothane concentrations that were approximately half those required for $\mathrm{MAC}^{7}$ This agrees with our data from baby rabbits, which show that both 0.5 MAC halothane ${ }^{8}$ and $0.5 \mathrm{MAC}$ nitrous oxide ( 70 per cent $)^{9}$ effectively abolish the baroresponse.

Forty per cent of these infants were hypotensive before ligation of the ductus arteriosus There are several possible reasons for this. First, the infants are usually fluid restricted and have been treated with potent diuretics to reduce their congestive heart failure. This makes them hypovolaemic. Second, anaesthetics depress the infant's cardiovascular system more than they do the adult's, ${ }^{5}$ in part because their sympathetic nervous system is incompletely developed, ${ }^{10}$ and sympathetic activity is important in maintaining the baroresponse. " As a consequence of their inadequate sympathetic nervous system, they fail to respond to hypotension by constricting their peripheral vessels ${ }^{12}$ and by increasing their heart rate. This leaves them vulnerable to alterations in blood pressure.

In summary, we were unable to demonstrate baroreceptor activity in preterm infants during light halothane anaesthesia. This would limit their ability to compensate for the frequent hypotension observed during halothane anaesthesia.

\section{REFERENCES}

1. KitTerman, J.A., EdMUNDS, L.H., JR., GREGORY G.A., et al. Patent ductus arteriosus in premature infants: Incidence, relation to pulmo- nary disease and management. N. Eng. Jour. Med. 287: 473-477 (1972).

2. Nicodemus, H.F., Nassiri-Rahimi, C. \& BaCHMAN, L. Median effective dose $\left(E_{50}\right)$ of halothane in adults and children. Anesthesiology 31; 344-348 (1969).

3. Bristow, J.D., Prys-Roberts, C., Fisher, A. et al. Effects of anesthesia on baroreflex control of heart rate in man. Anesthesiology 31:422428 (1969).

4. Duke, P.C., Fownes, D. \& WADE, J.G. Halothane depresses baroreflex control of heart rate in man. Anesthesiology 46: 184-187 (1977).

5. Barash, P.G., Glanz, S., Katz, J.D., et al. Ventricular function in children during halothane anesthesia. Anesthesiology 49: 79-85 (1978)

6. Brady, J.P. \& Tooley, W.H. Cardiovascular and respiratory reflexes in the newborn. Pediatric Clin. N. Amer. 13: 801-821 (1966).

7. Gregory, G.A., Munson, E. \& Eger, E.I., II The relationship between age and halothane requirement in man. Anesthesiology 30: 488 (1969).

8. Wear, R., Robinson, S. \& Gregory, G.A Effect of halothane on baroreceptor response in newborn and adult rabbits. Anesthesiology 51: S325 (1979).

9. Duncan, P., Gregory, G.A. \& Wade, J. The effect of Nitrous Oxide on the baroreceptor response of newborn and adult rabbits. Anesthesiology 53: \$341 (1980)

10. Freidman, W.F., Pool, P.E., Jacobowits, O., et al. Sympathetic innervation of the developing rabbit heart. Circ. Re. 23: 25-31 (1968).

11. RoIzen, M.F., Forbes, R., Miller, R.D., et al. Similarity between effects of pancuronium and atropine on plasma norepinephrine levels in man. J. Pharnacol. Exp. Ther. 211: 419-422 (1979).

12. Buckiey, N.M., Goatman, P.M., Reddy, G.D., et al. Age dependent cardiovascular effects of afferent stimulation of neonatal pigs. Biol. of Neonatc 30: 268-279 (1976).

\section{RÉSUMÉ}

Les anesthésiques dépriment la réponse des barorécepteurs chez l'adulte. Si tel était le cas chez les enfants, ceux-ci auraient beaucoup de difficulté à maintenir un débit cardiaque adéquat lors d'hypotension parce que le débit cardiaque de l'enfant dépend plus particulièrement de la fréquence que celui de l'adulte. Les auteurs ont étudié la réponse des barorécepteurs lors d'anesthésie générale chez le nouveau-né prématuré qui subissait une ligature du canal artériel.

Le rapport fréquence-pression artérielle systolique (réponse baroréceptrice) a été étudiée sur 53 nouveaux-nés prématurés $(1.065 \pm 205 \mathrm{~g})$ recevant halothane $0.5-1.0$ pour une ligature du canal artériel. La pression artérielle a été mesurée par la méthode sanglante dans 43 cas et par un appareil Doppler dans 10 cas. La fréquence cardiaque a été mesurée par des électrodes cutanées. Le rapport entre la fréquence et la pression systolique a été calculé avant et après la ligature du canal.

Immédiatement avant la ligature du canal artériel la pression systolique avait diminué de 33 pour cent lorsque comparée à l'état de veille sans changement de la fréquence cardiaque. Cing minutes après ligature, la pression a augmenté de 38 pour cent, sans changement de fréquence. Les différences entre pressions diastoliques étaient très significatives $(\mathrm{P}<$ $0.001)$ lors des dcux mesures. Les différences entre fréquences cardiaques ne l'étaient pas.

Ces données montrent l'absence de réponse baroréceptrice chez les prématurés pendant l'anesthésie légère à l'halothane, ce qui pourrait les empêcher de maintenir un débit cardiaque adéquat pendant l'hypotension. 